\title{
Implementing a University-Wide Academic Integrity Online Tutorial
}

\author{
Lyle Benson, Kristin Rodier, Rickard Enström, Evandro Bocatto \\ MacEwan University - School of Business, 10700-104 Ave, Edmonton AB Canada T5J 4S2
}

\begin{abstract}
This pilot study documents the creation of an Academic Integrity Online Tutorial at a Canadian university. The initial purpose of the Academic Integrity Online Tutorial was as a disciplinary procedure for students who had been found to have violated MacEwan University's Academic Integrity Policy. That purpose has changed from a penalizing and punishing process to an awareness and educational process. This study primarily describes the Academic Integrity Online Tutorial development process by focusing on the literature for Academic Integrity training for university students, the university-wide roll out of the Academic Integrity Online Tutorial, the construction of the Academic Integrity Online Tutorial, the pilot testing of the Academic Integrity Online Tutorial through quantitative and qualitative student feedback on the Academic Integrity Online Tutorial, lessons learned to improve the Academic Integrity Online Tutorial, and future research opportunities to evaluate the effectiveness of the Academic Integrity Online Tutorial.
\end{abstract}

Keywords: e-learning, higher educaton, ehtics, business, students 